\title{
Serotonin 5-HT 1 receptor binding in people with panic disorder: positron emission tomography study
}

Jon R. Nash, * Peter A. Sargent, E Eugenii A. Rabiner, Sean D. Hood, Spilios V. Argyropoulos, John P. Potokar, Paul M. Grasby and David J. Nutt

\section{Background}

The importance of the neurotransmitter serotonin $(5-\mathrm{HT})$ in the pathophysiology of anxiety is well known. A key role for postsynaptic $5-\mathrm{HT}_{1 \mathrm{~A}}$ receptors has recently been suggested in studies of genetic knockout mice.

\section{Aims}

To measure $5-\mathrm{HT}_{1 \mathrm{~A}}$ receptor binding in patients with panic disorder in the untreated state and after recovery on treatment with selective serotonin reuptake inhibitors (SSRIS).

\section{Method}

Nine symptomatic untreated patients with panic disorder, seven patients recovered on SSRI medication and nineteen healthy volunteers underwent a single positron emission tomography (PET) scan using the $5-\mathrm{HT}_{1 \mathrm{~A}}$ tracer $\left[{ }^{11} \mathrm{C}\right] \mathrm{WAY}$ 100635

The monoamine neurotransmitter serotonin (5-HT) has an important role in both the pathophysiology and treatment of anxiety and panic attacks. ${ }^{1,2}$ The strongest evidence that a specific abnormality of the serotonin system predisposes or contributes to anxiety comes from studies of the $5-\mathrm{HT}_{1 \mathrm{~A}}$ receptor. 'Knockout' mice bred without 5- $\mathrm{HT}_{1 \mathrm{~A}}$ receptors in the cerebral cortex and limbic system show increased anxiety behaviours ${ }^{3}$ and patients with panic disorder have been shown by challenge testing to have subsensitivity of these receptors. ${ }^{4}$ Furthermore, the azapirone $5-\mathrm{HT}_{1 \mathrm{~A}}$ agonist buspirone is licensed for the treatment of generalised anxiety disorder in the UK. In a systematic review of 36 trials of patients treated for generalised anxiety disorder azapirones, including buspirone, were found to be superior to placebo in short-term studies (4-9 weeks). ${ }^{5}$

The development of select radiotracers for the $5-\mathrm{HT}_{1 \mathrm{~A}}$ receptor now allows a direct examination of this receptor system in living patients with panic disorder. Neumeister et $a l^{6}$ reported the first full positron emission tomography (PET) study of $5-\mathrm{HT}_{1 \mathrm{~A}}$ binding in 16 unmedicated patients with panic disorder and 15 healthy controls. Regions of interest examined were limited to the anterior cingulate cortex, posterior cingulate cortex, anterior insula, mesiotemporal cortex, anterior temporopolar cortex and midbrain raphe - all areas of high $5-\mathrm{HT}_{1 \mathrm{~A}}$ binding. Lower $5-\mathrm{HT}_{1 \mathrm{~A}}$ binding occurred in anterior cingulate, posterior cingulate and raphe only in patients with panic disorder. Seven of the 16 patients with panic disorder had comorbid depression, although there was no difference in $5-\mathrm{HT}_{1 \mathrm{~A}}$ binding between the patients with panic disorder with comorbid depression and those without. The radiotracer used for Neumeister et al's study $\left[{ }^{18} \mathrm{~F}\right]$-FCWAY, gives a reliable signal subcortically, but quantification in cortical areas is limited because of retained fluoride signal in bone.

*These authors contributed equally to the work.

\section{Results}

In comparison with controls, both presynaptic and postsynaptic $5-\mathrm{HT}_{1 \mathrm{~A}}$ receptor binding was reduced in untreated patients, with the most significant reductions being in the raphe, orbitofrontal cortex, temporal cortex and amygdala. In recovered patients presynaptic binding was reduced, but there was no significant reduction in postsynaptic binding.

\section{Conclusions}

Panic disorder is associated with reduced $5-\mathrm{HT}_{1 \mathrm{~A}}$ receptor availability, which is also known to have a key role in depression.

\section{Declaration of interest}

Pump priming for the study was provided by a small grant from SmithKline Beecham (now GlaxoSmithKline). Funding detailed in Acknowledgements.

A further recent PET study using $\left[{ }^{11} \mathrm{C}\right]$ WAY-100635 found reduced $5-\mathrm{HT}_{1 \mathrm{~A}}$ binding in social anxiety disorder. ${ }^{8}$ That study compared 12 unmedicated male patients with social anxiety disorder with 18 healthy controls. Six of these patients had comorbid agoraphobia. Six regions of interest were examined a priori reduction of $5-\mathrm{HT}_{1 \mathrm{~A}}$ binding was found in the amygdala, anterior cingulate, insula, medial orbitofrontal cortex and raphe. After Bonferroni correction only the differences in the amygdala and anterior cingulate cortex remained significant. There was no significant correlation between state or trait anxiety scores and regional $5-\mathrm{HT}_{1 \mathrm{~A}}$ binding potential in both groups.

In this study, we used the PET tracer $\left[{ }^{11} \mathrm{C}\right]$ WAY-100635 which allows in vivo quantification of $5-\mathrm{HT}_{1 \mathrm{~A}}$ receptors with exquisite delineation and precision. ${ }^{9,10}$ Specifically, we wished to confirm the findings of Neumeister et $a l^{6}{ }^{6}$ extend the findings to look at more regions of interest and finally examine the effect of SSRI treatment. Our specific hypothesis was that patients with panic disorder would have reductions in $5-\mathrm{HT}_{1 \mathrm{~A}}$ receptor binding in anxiety-associated regions of the brain, and that SSRI treatment would not affect $5-\mathrm{HT}_{1 \mathrm{~A}}$ receptor availability.

\section{Methods}

\section{Recruitment of participants}

Nine unmedicated male patients with a primary diagnosis of panic disorder with or without agoraphobia (DSM-IV criteria) ${ }^{11}$ were recruited for PET scanning from the out-patient clinic of the Psychopharmacology Unit, Bristol Royal Infirmary. Seven patients were naïve to antidepressant therapy and two had taken a tricyclic antidepressant in the past. No patient had been on regular psychotropic medication in the previous 3 months. Exclusion criteria included current or comorbid major depression, serious physical illness, a history of bipolar affective disorder, current or 
past drug or alcohol dependence, current or previous treatment with mood stabilisers or antipsychotic medication, and current treatment with benzodiazepines. Nineteen healthy age-matched male volunteers were recruited for PET scanning from hospital staff and by advertisement, and acted as the control group. Exclusion criteria for volunteers were a history of psychiatric disorder, including drug or alcohol dependence, or a history of serious physical illness, including neurological disorders.

A further 7 male patients with panic disorder who were established on SSRI treatment were recruited for PET scanning from the same clinic. They had received open-label treatment with paroxetine hydrochloride (Table 1) or sertraline (1 patient: daily dose $50 \mathrm{mg}$, duration of treatment 24 months) and remained on treatment at the time of the scan. Clinical response was confirmed by a failure to meet DSM-IV criteria for current panic disorder, and an improvement of at least 2 points on the Clinical Global Impression (CGI) scale ${ }^{12}$ (much improved). Thus, in addition to the 9 untreated patients with panic disorder, we were able to study a second patient group comprising of 7 recovered patients with panic disorder on SSRI treatment.

All participants were screened for psychiatric disorders by clinical interview and using the Structured Clinical Interview for DSM-IV (SCID-I). ${ }^{13}$ A screening physical examination was performed and the Hamilton Rating Scale for Depression $(\mathrm{HRSD})^{14}$ was completed. The Beck Depression Inventory $(\mathrm{BDI})^{15}$ and the Hamilton Rating Scale for Anxiety (HRSA) ${ }^{16}$ were completed $1 \mathrm{~h}$ before each scan. All participants gave informed written consent to the study, which was approved by local ethics committees. Permission to administer the radioactive ligand was obtained from the UK Administration of Radioactive Substances Advisory Committee. Agreement to participate in the study was obtained from the general practitioner.

Positron emission tomography scanning was carried out at the Medical Research Council (MRC) Cyclotron Unit, Hammersmith Hospital, London. Patients were accompanied from Bristol by the treating psychiatrist on the day of the scan.

\section{Scanning protocol}

Scans were performed on an ECAT 935B PET camera (Control Technology, Inc., Knoxville, Tennessee, USA). This scanner acquires 31 planes of data with an axial field of view (FOV) of $10.5 \mathrm{~cm}$. The scanning method is described in full detail elsewhere. ${ }^{17}$

[Carbonyl ${ }^{11}$ C]WAY-100635 was prepared at the Cyclotron Unit, MRC Clinical Sciences Centre. A 10 min transmission scan was acquired in two-dimensional mode for correction of tissue attenuation. All participants then received $\left[{ }^{11} \mathrm{C}\right]$ WAY-100635 injected intravenously over $30 \mathrm{~s}$. Dynamic PET data were acquired in three-dimensional mode for $90 \mathrm{~min}$ after injection. The emission data were scatter corrected and reconstructed using a reprojection algorithm.

\section{Kinetic modelling of $\left[{ }^{11} \mathrm{C}\right]$ WAY-100635}

Quantitative tracer kinetic modelling was performed using a reference tissue compartmental model. Cerebellum was used as the reference tissue. The model allows estimation of binding potential and of the relative delivery of radioligand normalised to the cerebellum $\left(R_{1}\right)$. Parametric images of binding potential and $R_{1}$ were calculated as described elsewhere. ${ }^{10}$

\section{Regions of interest and statistical analysis}

Three groups were defined: untreated patients with panic disorder $(n=9)$, patients treated with SSRI medication $(n=7)$ and controls $(n=19)$. Regions of interest for 21 brain regions were defined using a previously validated database (for the 20 postsynaptic regions) and by hand for the raphe, and regional binding potential values were obtained by applying the regions of interest to the parametric binding-potential images and taking the mean voxel value. ${ }^{18}$ Statistical analysis of the regional binding potential and $\mathrm{R}_{1}$ data was performed using a single repeated-measures two-way analysis of variance (ANOVA) with Greenhouse-Geisser correction using SPSS version 10.1 for Windows, one factor being group (controls, untreated panic, treated panic) and the other factor being region. Where significant group or group $\times$ region interactions were obtained with ANOVA, post hoc $t$-tests were performed for binding potential values in individual regions of interest. Analysis was also performed separately for a composite of the 20 postsynaptic regions as a measure of global postsynaptic binding. All statistical tests were two-tailed and reported at $P<0.05$.

\section{Results}

\section{Participants}

Characteristics of the scanned participants are shown in Table 1. There were no differences between the three groups in terms of age and no differences in illness characteristics (duration of illness, history of agoraphobia or history of previous depression) between the untreated and treated patient groups. Untreated patients had higher anxiety scores than treated patients on the day of the scan but depression scores were not significantly different. The mean dose and duration of SSRI treatment are consistent with standard clinical treatment for panic disorder. ${ }^{2}$

\section{Region of interest analysis for binding potential}

The ANOVA of binding potential values for the three groups found a main effect of group ( $F=4.15$, d.f. $=2,32, P=0.025)$ as expected, a main effect of region $(F=81.925$, d.f. $=20,640, P<0.001)$ and a region $\times$ group interaction $(F=2.448$, d.f. $=40,640, P=0.007)$.

Post hoc unpaired $t$-tests found binding potential values to be significantly different for untreated patients $v$. controls in 17 of 21 regions. The areas with the most significant reductions were the raphe, amygdala, orbitofrontal cortex and anterior lateral temporal cortex $(P<0.01)$. Mean binding potential values were lower in the group of untreated patients with panic disorder, relative to the control group, by $24 \%$ in the raphe $(P<0.005 ;$ Fig. 1$)$ and by $16 \%$ in all postsynaptic regions combined $(P<0.05$; Fig. 2).

In contrast, for treated patients $v$. controls only 3 of the 21 identified regions were significantly different on post hoc $t$-testing (raphe, hippocampus and anterior medial temporal cortex at $P<0.05)$. No significant difference was seen in global postsynaptic binding for treated patients $v$. controls.

For treated $v$. untreated patients, only one region was significantly different (orbitofrontal cortex). No significant difference was seen in global postsynaptic binding for treated patients $v$. untreated patients.

\section{Region of interest analysis for $\mathbf{R}_{\mathbf{1}}$}

The ANOVA of $\mathrm{R}_{1}$ values for the three groups found no effect of group ( $F=1.83$, d.f. $=2,29, P=0.179$ ), but as expected a main effect of region $(F=82.3$, d.f. $=20,580, P<0.001)$ and a group $\times$ region interaction $(F=2.03$, d.f. $=40,580, P=0.02)$. Post hoc unpaired $t$-tests found $R_{1}$ values to be significantly different between the unmedicated patients and controls in one region of interest only (orbitofrontal cortex: $P<0.05$ ). 
Table 1 Profile of participants

\begin{tabular}{|c|c|c|c|}
\hline & Controls & $\begin{array}{l}\text { Untreated patients } \\
\text { with panic disorder }\end{array}$ & $\begin{array}{l}\text { Panic disorder patients } \\
\text { treated with SSRI medication }\end{array}$ \\
\hline n (all male) & 19 & 9 & 7 \\
\hline Age, years: mean (s.d.) & $41.3(12.5)$ & $37.6(11.4)$ & $45.4(12)$ \\
\hline Duration of illness, months: mean (s.d.) & - & $63.6(62.1)$ & $53.4(54.0)$ \\
\hline Current or previous agoraphobia, $n / N$ & - & $6 / 9$ & $6 / 7$ \\
\hline Previous depressive episode, $n / N$ & $0 / 19$ & $3 / 9$ & $4 / 7$ \\
\hline HRSA score, mean (s.d.) & - & $21.2(7.2)$ & $11.6(7.6)$ \\
\hline HRSD score, mean (s.d.) & - & $9.9(4.3)$ & $8.4(5.9)$ \\
\hline BDI score, mean (s.d.) & - & $14.1(9.3)$ & $12.0(8.9)$ \\
\hline Dose of paroxetine, mg: mean (s.d.) & - & - & $40(12.6)$ \\
\hline Duration of treatment, months: mean (s.d.) & - & - & $14.4(12.6)$ \\
\hline
\end{tabular}

\begin{tabular}{|c|c|c|c|c|c|}
\hline Region & $\begin{array}{l}\text { Controls } \\
(n=19)\end{array}$ & $\begin{array}{l}\text { Untreated panic } \\
\text { disorder }(n=9)\end{array}$ & Effect sizes & $\begin{array}{l}\text { Treated panic } \\
\text { disorder }(n=7)\end{array}$ & Effect sizes \\
\hline Raphe & $4.1(0.8)$ & $3.1(0.6)^{\star * *}$ & 1.3 & $3.3(0.6)^{*}$ & 1.0 \\
\hline Global postsynaptic regions & $4.3(0.5)$ & $3.6(0.9)^{*}$ & 1.4 & $4.2(0.7)$ & 0.2 \\
\hline Hippocampus & $6.2(1.0)$ & $5.1(1.7)^{\star}$ & 1.1 & $5.0(1.5)^{\star}$ & 1.2 \\
\hline Amygdala & $5.4(0.8)$ & $4.3(1.1)^{* *}$ & 1.4 & $5.2(0.9)$ & 0.3 \\
\hline Anterior medial temporal cortex & $5.3(0.9)$ & $4.0(1.4)^{*}$ & 1.4 & $4.4(0.7)^{\star}$ & 1.0 \\
\hline Anterior lateral temporal cortex & $5.3(1.0)$ & $4.0(1.0)^{* \star *}$ & 1.3 & $4.5(0.9)$ & 0.8 \\
\hline Parahippocampal gyrus & $6.1(1.0)$ & $5.2(1.3)^{*}$ & 0.9 & $6.0(0.4)$ & 0.1 \\
\hline Superior temporal gyrus & $4.9(0.7)$ & $4.1(1.1)^{*}$ & 1.1 & $4.8(0.6)$ & 0.1 \\
\hline Medial inferior temporal gyrus & $5.2(0.8)$ & $4.3(1.1)^{*}$ & 1.1 & $5.0(0.9)$ & 0.3 \\
\hline Fusiform gyrus & $6.1(0.9)$ & $5.3(1.3)$ & 0.9 & $6.2(0.7)$ & 0.1 \\
\hline Posterior temporal cortex & $4.6(0.7)$ & $3.8(0.8)^{*}$ & 1.1 & $4.4(0.7)$ & 0.3 \\
\hline Insula & $5.5(0.8)$ & $4.5(1.2)^{*}$ & 1.3 & $5.3(0.8)$ & 0.3 \\
\hline Anterior cingulate gyrus & $5.1(0.7)$ & $4.2(1.2)^{\star}$ & 1.3 & $4.9(0.8)$ & 0.3 \\
\hline Posterior cingulate gyrus & $3.8(0.6)$ & $3.6(0.6)$ & 0.3 & $4.2(1.1)$ & 0.7 \\
\hline Parietal lobe & $4.1(0.6)$ & $3.5(0.8)$ & 1.0 & $4.0(0.7)$ & 0.2 \\
\hline Occipital lobe & $3.1(0.5)$ & $2.7(0.5)$ & 0.8 & $3.2(0.6)$ & 0.2 \\
\hline Orbitofrontal cortex & $4.4(0.7)$ & $3.0(1.3)^{* * *}$ & 2.0 & $4.3(0.7)^{\dagger}$ & 0.1 \\
\hline Gyrus frontomedialis & $4.6(0.7)$ & $3.8(1.1)^{\star}$ & 1.1 & $4.3(0.9)$ & 0.4 \\
\hline Gyrus precentralis & $4.6(0.7)$ & $3.9(1.0)^{*}$ & 1.0 & $4.3(0.8)$ & 0.4 \\
\hline Gyrus frontoinferior & $3.8(0.6)$ & $3.2(0.8)^{*}$ & 1.0 & $3.7(0.7)$ & 0.2 \\
\hline Gyrus frontomedius & $3.9(0.6)$ & $3.3(0.8)^{\star}$ & 1.0 & $3.8(0.8)$ & 0.2 \\
\hline Gyrus frontosuperior & $3.9(0.6)$ & $3.2(1.0)^{*}$ & 1.2 & $3.6(0.8)$ & 0.5 \\
\hline
\end{tabular}

\section{Correlations with clinical variables}

There were no significant correlations of binding potentials against a range of clinical variables, including age, anxiety and depression scores, and treatment dose (data not shown).

\section{Discussion}

This PET study measured $5-\mathrm{HT}_{1 \mathrm{~A}}$ receptor density in both untreated and recovered patients with panic disorder. It demonstrates major differences in presynaptic raphe $5-\mathrm{HT}_{1 \mathrm{~A}}$ receptor density between controls and patients in both the untreated and recovered states. This study confirms the findings of Neumeister et $a l^{6}$ but extends their study to look at more regions of interest and addresses the effect of SSRI treatment in panic disorder. In untreated patients, lower binding was also seen in most postsynaptic regions, most significantly in the 'anxiety circuit' of the orbitofrontal cortex, temporal lobe and amygdala. ${ }^{19,20}$ In treated patients, lower binding was also seen in the raphe, but was much less widespread in postsynaptic regions.

\section{Reduced $5 \mathrm{HT}_{1 \mathrm{~A}}$ binding in panic disorder}

Recent evidence has specifically implicated $5-\mathrm{HT}_{1 \mathrm{~A}}$ receptors in the control of anxiety and suggested that reduced function of these receptors may contribute to the development of pathological anxiety.

(a) It has been shown in animal models that the anxiolytic activity of SSRIs is dependent on increased binding of serotonin to postsynaptic $5-\mathrm{HT}_{1 \mathrm{~A}}$ receptors. ${ }^{21}$ 


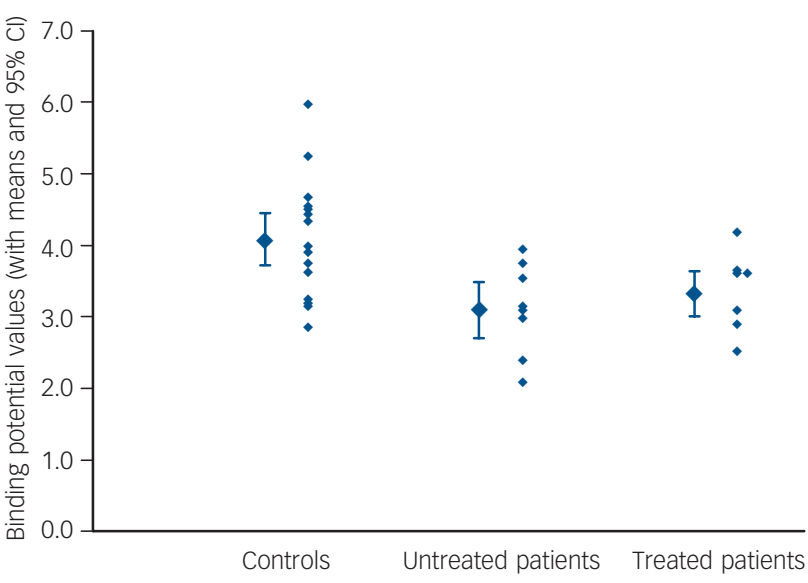

Fig. 1 Raphe binding potential values.

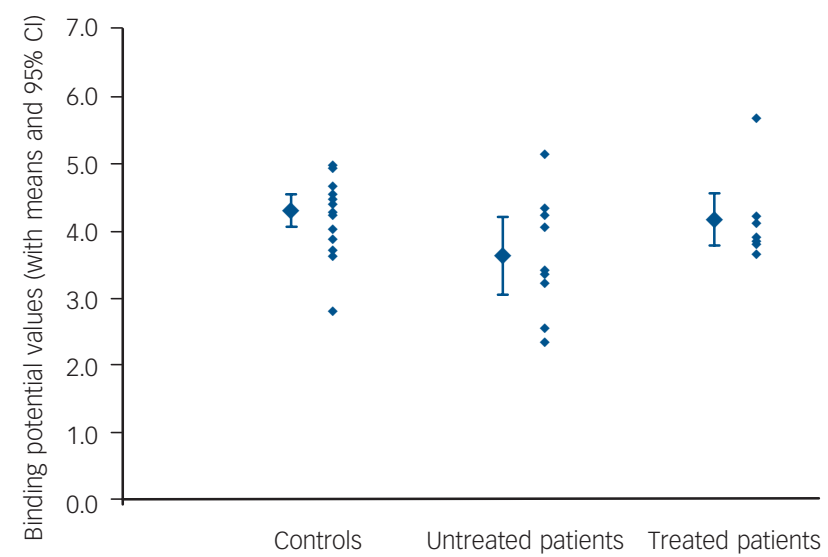

Fig. 2 Global postsynaptic binding potential values.

(b) Some patients with anxiety disorders who have recovered on SSRI treatment can be made symptomatic by acutely depleting tryptophan, the amino acid precursor of serotonin, suggesting a persisting abnormality of postsynaptic serotonin receptors. ${ }^{22,23}$

(c) A specific hypofunction of both presynaptic and postsynaptic $5-\mathrm{HT}_{1 \mathrm{~A}}$ receptors in patients with panic disorder has been indicated by challenge testing with the $5-\mathrm{HT}_{1 \mathrm{~A}}$ agonist ipsapirone. Patients showed reduced hypothermic and neuroendocrine effects compared with controls. ${ }^{4}$

(d) Mice bred with genetic knockout of the $5-\mathrm{HT}_{1 \mathrm{~A}}$ receptor have repeatedly been shown to demonstrate elevated levels of anxiety, and a technique that allowed the 'switching on' of the $5-\mathrm{HT}_{1 \mathrm{~A}}$ gene at various stages of development showed that receptors in the forebrain (corresponding to the human cortex and limbic system) had a critical role in the development of anxiety behaviour. ${ }^{24}$

Our finding of a reduction in postsynaptic $5-\mathrm{HT}_{1 \mathrm{~A}}$ receptor binding in patients with untreated panic disorder is consistent with the reported subsensitivity to pharmacological challenge and with the model of anxiety postulated from studies of $5-\mathrm{HT}_{1 \mathrm{~A}}$ knockout mice. Furthermore, functional brain imaging studies have revealed that circuits involving the amygdala, temporal cortex and orbitofrontal cortex mediate the perception of threat and the experience of anxiety in humans. ${ }^{25,26}$ The prominent localisation of reduced $5-\mathrm{HT}_{1 \mathrm{~A}}$ binding in these regions in our study suggests an aetiological role in panic disorder.

Evidence for altered function of gamma-aminobutyric acid and serotonergic neurotransmission in patients with panic disorder is growing, $6,27,28$ although a primary aetiological role has yet to be established. Although panic may originate in brainstem structures, ${ }^{29}$ recent studies have identified an inhibitory role for specific cortical regions, including the orbitofrontal cortex. ${ }^{30}$ A deficit of $5-\mathrm{HT}_{1 \mathrm{~A}}$ receptors, as found in our study, may lead to a relative decrease in the ability of the brain to control panic anxiety.

Interesting comparisons can be drawn between our findings and those from PET studies of 5- $\mathrm{HT}_{1 \mathrm{~A}}$ binding in patients with depression. ${ }^{12,31}$ These studies also found lower presynaptic and global postsynaptic $5-\mathrm{HT}_{1 \mathrm{~A}}$ binding in patients compared with controls. This similarity is not unexpected as anxiety and depressive disorders have a clinical overlap, both being brought on by stress-related factors and both responding to SSRI medication. Although there were some differences between the disorders in the postsynaptic regions showing the greatest alterations in binding (orbitofrontal and anterior temporal cortices in panic, anterior cingulate in depression), there is a consistent finding of a general reduction in postsynaptic receptors.

Our findings in untreated patients also correspond with those of the previously reported study ${ }^{6}$ of $5-\mathrm{HT}_{1 \mathrm{~A}}$ receptor binding in patients with untreated panic disorder using $\left[{ }^{18} \mathrm{~F}\right]$-FCWAY, in which where a reduction in binding was found in the anterior cingulate, posterior cingulate and raphe regions. Using a different radiotracer and quantification method, $5-\mathrm{HT}_{1 \mathrm{~A}}$ receptor binding was reduced in two of these three regions in our study. We also found more widespread reductions of $5-\mathrm{HT}_{1 \mathrm{~A}}$ binding; however, further comparison with the Neumeister et al study is restricted as only six regions of interest were reported in total and receptor quantification with this radioligand is problematic in cortical areas owing to the retention of the fluoride signal in adjacent skull bones. ${ }^{6}$

This research finding of reduced $5-\mathrm{HT}_{1 \mathrm{~A}}$ binding has therefore now been replicated in both depression and panic disorder, and has important implications for our understanding of the aetiology of these disorders. Animal studies have shown that $5-\mathrm{HT}_{1 \mathrm{~A}}$ binding can be altered by both genetic and environmental factors, including physical and biological stressors, ${ }^{32}$ and that altered $5-\mathrm{HT}_{1 \mathrm{~A}}$ binding is associated with other abnormalities of serotonin function. ${ }^{33}$ As neuroimaging techniques allow the replication of these findings in human studies, it becomes possible to create a hypothesis of reduced serotonergic neurotransmission via $5-\mathrm{HT}_{1 \mathrm{~A}}$ receptors as a biological pathway that can bring together such diverse factors as genetic predisposition, early life trauma, physical illness and stressful life events in the aetiology of anxiety and affective disorders.

\section{Effect of SSRI treatment on $5-\mathrm{HT}_{1 \mathrm{~A}}$ binding}

There was no difference in global postsynaptic binding between recovered patients on SSRI medication and controls, and binding was significantly lower in only two of the forebrain regions and the raphe compared with controls. In animal studies, Welner et al ${ }^{34}$ and $\mathrm{Li}$ et $a l^{35}$ found reduced $5-\mathrm{HT}_{1 \mathrm{~A}}$ binding in the midbrain following chronic fluoxetine administration. However, other animal studies have found no effects of SSRIs on $\left[{ }^{3} \mathrm{H}\right] 8-\mathrm{OH}-\mathrm{DPAT}$ binding in any brain region. ${ }^{36-39}$ The smaller differences from controls in postsynaptic binding in the SSRI-treated group compared with the untreated group may be due to a lack of power to detect a difference between SSRI-treated patients $(n=7)$ and controls. 
The mean binding potential values for this group were intermediate between those of the unmedicated patients with panic disorder and the healthy controls. Larger numbers of participants may have clarified whether the binding potential values for these patients does indeed lie between the untreated patients and controls.

An alternative explanation is that SSRI treatment of panic disorder may be associated with 'normalisation' of $5-\mathrm{HT}_{1 \mathrm{~A}}$ binding. This is probably not a direct effect of SSRI treatment, as treatment was not associated with altered binding in our study of patients with depression, although SSRI treatment in this study was of a shorter duration and at a lower dose. ${ }^{17}$

Our finding in untreated patients with panic disorder of reduced raphe and postsynaptic $5-\mathrm{HT}_{1 \mathrm{~A}}$ binding may be related to the chronic stress associated with, and possibly causal of, anxiety. Stress has been shown in animals to reduce $5-\mathrm{HT}_{1 \mathrm{~A}}$ receptor density and function and, via overstimulation of glucocorticoid receptors, also leads to a loss of dendritic spines in neurons. ${ }^{40}$ Interestingly, although previous studies had not found a correlation between cortisol levels and 5- $\mathrm{HT}_{1 \mathrm{~A}}$ expression in patients with depression, ${ }^{31}$ a strongly negative correlation was recently reported between hippocampal $5-\mathrm{HT}_{1 \mathrm{~A}}$ expression and cortisol levels in social anxiety disorder. ${ }^{41} \mathrm{~A}$ 'normalisation' of postsynaptic $5-\mathrm{HT}_{1 \mathrm{~A}}$ binding with treatment could therefore be explained by a reduction in stress associated with recovery.

Anxiety and depressive disorders are frequently coexisting conditions and have many clinical similarities, including sleep disturbance, fatigue, reduced concentration and irritability. Both respond to treatment with serotonergic antidepressants, which suggests a commonality in underlying pathophysiology. Our imaging data suggest that both disorders share at least one neurochemical pathophysiological feature, namely reduced 5- $\mathrm{HT}_{1 \mathrm{~A}}$ binding. Our findings are also consistent with preclinical and clinical studies of anxiety, including the findings that reduced $5-\mathrm{HT}_{1 \mathrm{~A}}$ receptor binding is causal of anxiety-like behaviours in $5-\mathrm{HT}_{1 \mathrm{~A}}$ knockout mice, ${ }^{24}$ and that patients with panic disorder have impaired $5-\mathrm{HT}_{1 \mathrm{~A}}$ receptor function in neuroendocrine challenge tests. ${ }^{4}$

The numbers of individuals participating in this study are low, but not untypical for PET studies of this kind. None the less, significant reductions in binding potential values were still found in 17 out of 21 brain regions in unmedicated patients with panic disorder compared with healthy controls. On the other hand, reductions in binding potential were only found in 3 out of the 21 regions in the SSRI-treated patients. Less confidence can be placed in the latter finding.

It would be of considerable interest to see whether similar changes in binding potential occur in female patients with panic disorder as the prevalence of this condition is about twice as high in women as in men.

Positron emission tomography is a highly sensitive procedure and it is important to consider sources of bias in the methodology. Our study did not include estimations of brain volume, partly because the magnetic resonance imaging scanner encloses the patient to an extent that most patients with untreated panic disorder would find too frightening. It seems reasonable to proceed without these measurements as there is no evidence from other studies that panic disorder is associated with reduced brain volume. ${ }^{21}$ Although the PET scanner is less oppressive than magnetic resonance imaging, our untreated patients were significantly more anxious than controls prior to the scan and subjectively found the scanning procedure more anxiogenic than those in the treated and control groups. This could in theory have contributed to the differences seen, although our evidence suggests that acute physiological alterations of serotonin in humans do not significantly affect cortical WAY-100635 binding, ${ }^{18}$ and evidence from animal studies suggests that acute stress does not lead to a significant reduction in $5-\mathrm{HT}_{1 \mathrm{~A}}$ binding. ${ }^{42}$ Variations in cerebral blood flow of the magnitude expected between anxious patients and controls are unlikely to affect the $\left[{ }^{11} \mathrm{C}\right]$-WAY 100635 signal. ${ }^{10}$ Finally, it has previously been shown that $5-\mathrm{HT}_{1 \mathrm{~A}}$ binding reduces with age, and although the age differences between groups were not significant, our findings of reduced binding were in the group with the younger mean age.

In part because of the cost of PET studies and the logistical problems involved in scanning individuals, participant numbers in PET studies tend to be low and replication of results is therefore acknowledged to be very important in the field. Thus, our study is important as it confirms the findings of Neumeister et $a l^{6}{ }^{6}$ extends these to look at more regions of interest and examines the effect of SSRI treatment.

\section{Clinical implications}

Positron emission tomography demonstrates that patients with untreated panic disorder have lower $5-\mathrm{HT}_{1 \mathrm{~A}}$ receptor binding compared with controls. This finding is consistent with predictions from animal models of anxiety. This reduction in binding is especially significant in the orbitofrontal cortex, temporal lobes and amygdala - these regions are known to control anxiety responses and reduced $5-\mathrm{HT}_{1 \mathrm{~A}}$ binding in these areas may be a biological factor that confers vulnerability to anxiety disorders.

Our imaging data shows that reduced $5-\mathrm{HT}_{1 \mathrm{~A}}$ binding is a pathophysiological feature of both panic disorder and depression, and may represent a common neurobiological pathway in the development of these stress-related disorders.

\section{Limitations}

The observations of the effects of SSRI treatment would have been more powerful if patients had been scanned before and after treatment. In addition, owing to the use of ionising radiation, only male patients were included in the study.

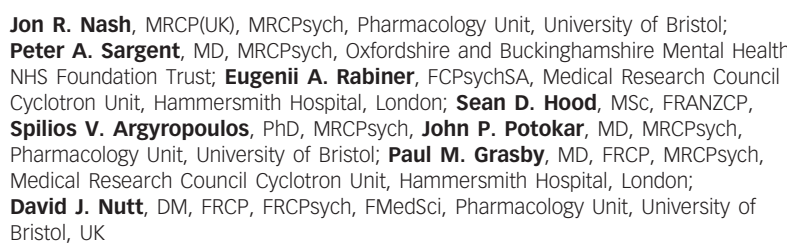

Jon R. Nash, MRCP(UK), MRCPsych, Pharmacology Unit, University of Bristol; Peter A. Sargent, MD, MRCPsych, Oxfordshire and Buckinghamshire Mental Health NHS Foundation Trust; Eugenii A. Rabiner, FCPsychSA, Medical Research Council Cyclotron Unit, Hammersmith Hospital, London; Sean D. Hood, MSC, FRANZCP, Spilios V. Argyropoulos, PhD, MRCPsych, John P. Potokar, MD, MRCPsych,
P Pharmacology Unit, University of Bristol; Paul M. Grasby, MD, FRCP, MRCPsych, Medical Research Council Cyclotron Unit, Hammersmith Hospital, London; David J. Nutt, DM, FRCP, FRCPsych, FMedSci, Pharmacology Unit, University of Bristol, UK

Correspondence: Professor David Nutt, Psychopharmacology Unit, University of Bristol, Dorothy Hodgkins Building, Whitson Street, Bristol BS1 3NY, UK. Email: David.J.Nutt@bristol.ac.uk

First received 4 Jun 2007, final revision 26 Feb 2008, accepted 18 Apr 2008

\section{Acknowledgements}

This study was initiated by a grant from SmithKline Beecham, and the scanning costs were covered by a program grant to P.M.G. from the MRC. These data were presented in poster form at the British Association for Psychopharmacology Summer Meeting (20-23 July 2003, Cambridge, UK) and the annual European College of Neuropsychopharmacology Congress (9-13 October 2004, Stockholm, sweden).

\section{References}

1 Bell CJ, Nutt DJ. Serotonin and panic. Br J Psychiatry 1998; 172: 465-71.

2 Baldwin DS, Anderson IM, Nutt DJ, Bandelow B, Bond A, Davidson JR, den Boer JA, Fineberg NA, Knapp M, Scott J, Wittchen HU. Evidence-based guidelines for the pharmacological treatment of anxiety disorders: 
recommendations from the British Association for Psychopharmacology. J Psychopharmacol 2005; 19: 567-96.

3 Parks $\mathrm{CL}$, Robinson PS, Sibille E, Shenk T, Toth M. Increased anxiety of mice lacking the serotonin $_{1 \mathrm{~A}}$ receptor. Proc Natl Acad Sci USA 1998; 95: 10734-9.

4 Lesch KP, Wiesmann M, Hoh A, Müller T, Disselkamp-Tietze J, Osterheider M, Schulte HM. 5- $\mathrm{HT}_{1 \mathrm{~A}}$ receptor-effector system responsivity in panic disorder Psychopharmacology (Berl) 1992; 106: 111-7.

5 Chessick CA, Allen $M H$, Thase $M$, Batista Miralha da Cunha AB, Kapczinsk FF, de Lima MS, dos Santos Souza JJ. Azapirones for generalized anxiety disorder. Cochrane Database Syst Rev 2006; (3): CD006115.

6 Neumeister A, Bain E, Nugent AC, Carson RE, Bonne O, Luckenbaugh DA, Eckelman W, Herscovitch P, Charney DS, Drevets WC. Reduced serotonin type 1A binding in panic disorder. J Neurosci 2004; 24: 589-91.

7 Carson RE, Wu Y, Lang L, Ma Y, Der MG, Herscovitch P, Eckelman WC. Brain uptake of the acid metabolites of F-18-labelled WAY100635 analogs. J Cereb Blood Flow Metab 2003; 23: 249-60.

8 Lanzenberger RR, Mitterhauser M, Spindelegger C, Wadsak W, Klein N, Mien LK, Holik A, Attarbaschi T, Mossaheb N, Sacher J, Geiss-Granadia T, Kletter K, Kasper S, Tauscher J. Reduced serotonin-1A receptor binding in social anxiety disorder. Biol Psychiatry 2007; 61: 1081-9.

9 Pike VW, McCarron JA, Lammertsma AA, Osman S, Hume SP, Sargent PA, Bench CJ, Cliffe IA, Fletcher A, Grasby PM. Exquisite delineation of 5-HT receptors in human brain with PET and [carbonyl- ${ }^{11} \mathrm{C}$ ]WAY-100635. Eur J Pharmacol 1996; 301: R5-7.

10 Gunn RN, Sargent PA, Bench CJ, Rabiner EA, Osman S, Pike VW, Hume SP, Grasby PM, Lammertsma AA. Tracer kinetic modeling of the 5- $\mathrm{HT}_{1 \mathrm{~A}}$ recepto ligand [carbonyl-11C]WAY-100635 for PET. Neuroimage 1998; 8: 426-40.

11 American Psychiatric Association. Diagnostic and Statistical Manual of Mental Disorders (4th edn) (DSM-IV). APA, 2004.

12 Guy W. ECDEU Assessment Manual for Psychopharmacology. US Departmen of Health, Education and Welfare publication (ADM) 76-338. National Institute of Mental Health, 1976: 179-222.

13 First MB, Spitzer RL, Gibbon M, Williams J. Structured Clinical Interview for DSM-IV Axis I Disorders, Research Version, Patient Edition (SCID-P). New York State Psychiatric Institute, Biometrics Research, 1997.

14 Hamilton M. A rating scale for depression. J Neurol Neurosurg Psychiatry 1960; 23: 56-62

15 Beck AT, Ward $\mathrm{CH}$, Mendelson M, Mock J, Erbaugh J. An inventory for measuring depression. Arch Gen Psychiatry 1961; 4: 561-71.

16 Hamilton M. The assessment of anxiety states by rating. $\mathrm{Br} J$ Med Psychol 1959; 32: 50-5.

17 Sargent PA, Kjaer KH, Bench CJ, Rabiner EA, Messa C, Meyer J, Gunn RN, Grasby PM, Cowen PJ. Brain serotonin ${ }_{1 A}$ receptor binding measured by positron emission tomography with $\left[{ }^{11} \mathrm{C}\right] \mathrm{WAY}$-100635: effects of depression and antidepressant treatment. Arch Gen Psychiatry 2000; 57: 174-80.

18 Rabiner EA, Messa C, Sargent PA, Husted-Kjaer K, Montgomery A, Lawrence $A D$, Bench CJ, Gunn RN, Cowen P, Grasby PM. A database of [(11)C]WAY100635 binding to $5-\mathrm{HT}(1 \mathrm{~A})$ receptors in normal male volunteers: normative data and relationship to methodological, demographic, physiological, and behavioral variables. Neuroimage 2002; 15: 620-32.

19 Rosen JB, Schulkin J. From normal fear to pathological anxiety. Psychol Rev 1998; 105: 325-50.

20 Cannistraro PA, Rauch SL. Neural circuitry of anxiety: evidence from structural and functional neuroimaging studies. Psychopharmacol Bull 2003; 37: 8-25.

21 Blier $\mathrm{P}$, Ward NM. Is there a role for $5-\mathrm{HT}_{1 \mathrm{~A}}$ agonists in the treatment of depression? Biol Psychiatry 2003; 53: 193-203.

22 Bell C, Forshall S, Adrover M, Nash J, Hood S, Argyropoulos S, Rich A, Nutt DJ. Does 5-HT restrain panic? A tryptophan depletion study in panic disorder patients recovered on paroxetine. J Psychopharmacol 2002; 16: 5-14.

23 Argyropoulos SV, Hood SD, Adrover M, Bell CJ, Rich AS, Nash JR, Rich NC, Witchel HJ, Nutt DJ. Tryptophan depletion reverses the therapeutic effect of selective serotonin reuptake inhibitors in social anxiety disorder. Biol Psychiatry 2004; 56: 503-9.
24 Gross C, Zhuang X, Stark K, Ramboz S, Oosting R, Kirby L, Santarelli L, Beck S, Hen R. Serotonin ${ }_{1 A}$ receptor acts during development to establish normal anxiety-like behaviour in the adult. Nature 2002; 416: 396-400.

25 Gorman JM, Kent JM, Sullivan GM, Coplan JD. Neuroanatomical hypothesis of panic disorder, revised. Am J Psychiatry 2000; 157: 493-505.

26 Malizia AL. Brain imaging and anxiety disorders. In Anxiety Disorders (eds DJ Nutt \& JC Ballenger): 201-28. Blackwell Science, 2003.

27 Malizia AL, Cunningham VJ, Bell CJ, Liddle PF, Jones T, Nutt DJ. Decreased brain GABA(A)-benzodiazepine receptor binding in panic disorder: preliminary results from a quantitative PET study. Arch Gen Psychiatry 1998; 55: 715-20.

28 Maron E, Kuikka JT, Shlik J, Vasar V, Vanninen E, Tiihonen J. Reduced brain serotonin transporter binding in patients with panic disorder. Psychiatry Res 2004; 132: 173-81.

29 Bailey JE, Argyropoulos SV, Lightman SL, Nutt DJ. Does the brain noradrenaline network mediate the effects of the $\mathrm{CO} 2$ challenge? J Psychopharmacol 2003; 17: 252-9.

30 Kent JM, Coplan JD, Mawlawi O, Martinez JM, Browne ST, Slifstein M, Martinez D, Abi-Dargham A, Laruelle M, Gorman JM. Prediction of panic response to a respiratory stimulant by reduced orbitofrontal cerebral blood flow in panic disorder. Am J Psychiatry 2005; 162: 1379-81.

31 Drevets WC, Frank E, Price JC, Kupfer DJ, Greer PJ, Mathis C. Serotonin type1A receptor imaging in depression. NuCl Med Biol 2000; 27: 499-507.

32 McKittrick CR, Blanchard DC, Blanchard RJ, McEwen BS, Sakai RR. Serotonin receptor binding in a colony model of chronic social stress. Biol Psychiatry 1995; 37: 383-93.

33 Ase AR, Reader TA, Hen R, Riad M, Descarries L. Regional changes in density of serotonin transporter in the brain of $5-\mathrm{HT} 1 \mathrm{~A}$ and 5 -HT1B knockout mice and of serotonin innervation in the 5-HT1B knockout. J Neurochem 2001; 78 : 619-30.

34 Welner SA, De Montigny C, Desroches J, Desjardins P, Suranyi-Cadotte BE. Autoradiographic quantification of serotonin ${ }_{1 \mathrm{~A}}$ receptors in rat brain following antidepressant drug treatment. Synapse 1989; 4: 347-52.

35 Li Q, Brownfield MS, Levy AD, Battaglia G, Cabrera TM, Van de Kar LD. Attenuation of hormone responses to the $5-\mathrm{HT}_{1 \mathrm{~A}}$ agonist ipsapirone by longterm treatment with fluoxetine, but not desipramine, in male rats. Biol Psychiatry 1994; 36: 300-8.

36 Hensler JG, Kovachich GB, Frazer A. A quantitative autoradiographic study of serotonin $_{1 \mathrm{~A}}$ receptor regulation: effect of 5,7-dihydroxytryptamine and antidepressant treatments. Neuropsychopharmacology 1991; 4: 131-44.

37 Le Poul E, Lima L, Laporte AM, Even C, Doucet E, Fattaccini CM, Laaris N Hamon $\mathrm{M}$, Lanfumey L. Central serotonin receptors and chronic treatment with selective serotonin reuptake inhibitors: comparison between fluoxetine and paroxetine [French]. Encephale 1995; 21: 123-32.

38 Li Q, Muma NA, Van de Kar LD. Chronic fluoxetine induces a gradual desensitization of $5-\mathrm{HT}_{1 \mathrm{~A}}$ receptors: reductions in hypothalamic and midbrain $\mathrm{G}_{\mathrm{i}}$ and $\mathrm{G}_{\mathrm{o}}$ proteins and in endocrine responses to $5-\mathrm{HT}_{1 \mathrm{~A}}$ agonist. J Pharmacol Exp Ther 1996: 279: 1035-42.

39 Li Q, Muma NA, Battaglia G, Van de Kar LD. A desensitization of hypothalamic $5-\mathrm{HT}_{1 \mathrm{~A}}$ receptors by repeated injections of paroxetine: reduction in the levels of $G_{i}$ and $G_{0}$ proteins and neuroendocrine responses, but not in the density of 5-HT 1 A receptors. J Pharmacol Exp Ther 1997; 283: $1581-90$.

40 Duman RS. Depression: a case of neuronal life and death? Biol Psychiatry 2004; 56: 140-5.

41 Lanzenberger R, Wadsak W, Spindelegger C, Mitterhauser M, Klein N, Mien LK, Attarbaschi T, Mossaheb N, Sacher J, Holik A, Geiss-Granadia T, Kletter K, Kasper S. Hippocampal serotonin-1A receptor binding correlates with cortisol plasma levels in social anxiety disorder. Eur Neuropsychopharmacol 2006; 16 (suppl 4): S270.

42 Steciuk M, Kram M, Kramer GL, Petty F. Acute stress does not alter 5-HT 1 A receptor density. Prog Neuropsychopharmacol Biol Psychiatry 2000; 24 : $155-61$. 